\title{
MUTUALITY, EMPOWERMENT AND FIT IN CREATIVE KNOWLEDGE WORK PERFORMANCE
}

\author{
Laura GAIŽAUSKIENË* Živilè TUNČIKIENĖ \\ Business Department, Business Management Faculty, Vilnius Gediminas Technical University, \\ Sauletekio al. 11, LT-10223, Vilnius, Lithuania \\ ${ }^{*}$ E-mail: laura.gaizauskiene@vgtu.lt
}

\begin{abstract}
Purpose - the purpose of the article is to reveal the role of the three dimensions - mutuality, empowerment and fit - in organizational performance and productivity with the main emphasis on creative knowledge work. The scientific problem could be expressed in the goal to identify the relationships between these elements and elicite research gaps to be filled.
\end{abstract}

Research methodology - the methodology of the article used consists of scientific literature review, analyses and synthezes, structural equation modelling.

Findings - in the part of the literature review the theoretical models are presented as the base and grounding for the creation of an empirical model.

Research limitations - the main limitation of this research is the exclusion of risks and hazards in the workplaces as the focus is on the main positive factors which influence the performance. Avoiding negative dimensions limits prevention of emerging forces which usually require recourses. By investigating risk elements may give a more accurate view to the whole picture in organizations.

Practical implications - the practical implication of the research results may identify the areas in SHRM policies which could require new or improved practices.

Originality/Value - there are very limited number of researches which combine human resource and knowledge management, so the main novelty of this study is to answer one questions specific to one discipline by using findings of the other field.

Keywords: mutuality, empowerment, fit, creative knowledge work, performance.

JEL Classification: D53.

Conference topic: Contemporary Organizations Development Management.

\section{Introduction}

Management of post-modern organisations as elements of the ecosystem as well as management of knowledge work require long lasting solutions to sustain and compete as short-term intentions may have a devastating impact on the whole economic system. Organisations that perform in the knowledge economy sector are dependent on their workers (Čiutiené, 2006) and society cultural norms (Griffin, 2015) more than traditional industrial organisations. Employees in this new sector are called knowledge workers and management of their work productivity and/or performance is the main concerns for practitioners as well as for scholars who are looking for new ways of working that would lead to desired outcomes. The topic of knowledge management definition and perception of this category workers are well developed in knowledge management literature, interestingly underdeveloped in the literature of human resource management. There is emerging research interest in combining these two managerial fields which would follow the works of e.g. Kianto, Shujahat, Hussain, Nawaz, F. and Ali (2018), Shujahat (2017), etc. Explaining this via different focus lenses, approaches and backgrounds could be useful, but from the holistic point of view to narrow and uninformative. The main intention of this paper is to investigate some concept and standpoints used in human resource management and try to adapt to knowledge management context. In order to achieve the purpose, the following concepts were selected: mutuality, empowerment and fit, and their importance in post-modern organisation performance management will be explained with the focus on compatibility process between knowledge workers and workplaces. 


\section{Literature review}

\subsection{Creative knowledge work performance}

Performance measurement is the essence of the management process. Knowledge work could be measured in two ways: as productivity of knowledge worker category and as the performance of the knowledge-intensive organisation.

Knowledge Worker Productivity. Many researchers (Heynes, 2008; Bosch-Sijtsema, Ruohomäki, \& Vartiainen, 2009; Palvalin, 2017; Palvalin, Van der Voordt, \& Jylhä, 2017; Pashkevich, 2016 Dahooie, Arsalan, \& Shojai, 2018; Iazzolino \& Laise, 2018; Kianto et al., 2018) who investigates category of knowledge workers or issues related to their work state that the biggest problem is their productivity measurement. It is not surprising by knowing the legacy and influence of P. Drucker's seminal works through which this idea was spread out. Ramirez and Nembhard (2004) fifteen years ago have summarized the scientific attempts to capture the knowledge worker's productivity. But the discussion is still open. Some authors (Koopmans et al., 2011; Laihonen, Jääskeläinen, Lönnqvist, \& Ruostela, 2012) argue that there is another concept closely related to productivity - performance. In recent years the theoretical considerations were updated by offering new insights of solving this problem (Dahooie et al., 2018; Iazzolino \& Laise, 2018). Based on abovementioned works, there could be concluded that there are three main streams of understanding and measuring knowledge work productivity:

- Perceived productivity;

- Technical productivity;

- Value-added productivity.

Some scholars (Kubik, 2015; Iazzolino \& Laise, 2016) emphasize that the value creation should be the main concern in order to survive for organisations so the attention should be focused on the measurement of knowledge work performance via created value. This approach of productivity measurement includes market perspective as the social impact becomes incorporated and customer perspective becomes the inspiration for innovation and individualized application (Kähkönen \& Lintukangas, 2018). Iazzolino and Laise (2018) dispute on the Drucker's knowledge worker productivity theory by suggesting that in order to adopt Public proposal for value added measurement approach, traditional managerial mentality when human resources are interpreted as only costs. This logic is too narrow in the long run. The value added perspective is wider as it takes into account not only the factors of productivity within the organisation, but also includes the stakeholder perspective.

What is more, knowledge work performance is stated to be an umbrella term which captures productivity term (Okkonen, 2004). Abedi, Shamizanjani, Moghadam, and Bazrafshan (2018) argue that employee performance appraisal is probably the best way to capture knowledge workers productivity. Table 1 illustrates that productivity or performance measurement is understood as aggregated indicators. This manifestation leads to another stream of research.

Knowledge work performance. In the literature of performance measurement, there are several seminal works with the intention in a normative manner to capture the elements of performance management, i.e. Kaplan and Norton (2006), Neely, Adams and Crowe (2001). In the knowledge economy, the main factor for growth is indicated as innovation. Innovation in the workplace context is any new intervention which creates value not only for the employee and the organisation but for other stakeholders. In the context of relations between knowledge workers and workplaces, it could be captured as new ways of working, innovative work performance or entrepreneurial behaviour. This kind of behaviour is impossible without creativity which is always incorporated in knowledge work (Loo, 2017). In constructing and understanding relations among selected elements, it is important to emphasize this insight, as innovative behaviour is seen as a positive and beneficial outcome in knowledge-based organizations.

Table 1. Typology of Knowledge Worker Productivity (source: compiled by authors based on Heynes, 2008; Iazzolino \& Laise, 2018)

\begin{tabular}{|l|l|}
\hline \multicolumn{1}{|c|}{ Types of productivity } & \multicolumn{1}{c|}{ Indicators for measurement } \\
\hline Technical Productivity & $\begin{array}{l}\text { Quantity of the Product of Knowledge (output) } \\
\text { Quantity of Knowledge (input) }\end{array}$ \\
\hline Economical Productivity & $\begin{array}{l}\text { Value Added from Investment in Human Capital } \\
\text { Investment in Human Capital }\end{array}$ \\
\hline Perceived Productivity & Quality of Job and Well-being at the Workplace \\
\hline
\end{tabular}

\subsection{Organizational fit}

Many researches have been done in the field of fit and it already counts more than 100 years. Concept of fit is widely integrated in any form of human resource management. Due to this it has very strong theoretical and practical reasoning in any construct it appears. Based on the previous scientific works, scholars of organizational behaviour come with the conclusion that there are five dimensions of fit: person-person, person-job, person-group, person- organization and person-vocation. From the perspective of the organization, not all of them are equally important as the distance of 
control in terms of time and power differ. Boselie (2014) argue that the ones that attention should be paid on are personjob and person-organization fit. However, these two forms of fit could be extracted into forms of the match in considering mutuality as the reciprocal exchange.

Boxall (2013) gives the insight that analyses of human resources as separate functions (selection, training, appraisal and remuneration) has lost the main principle which must be kept in order to meet the organisational expectations laid on its employees. Mutuality is the main indicator which should be incorporated in the three-step evaluation procedure (matching of capability, commitment and contribution) by taking into account interests of both sides in forming sustainable employment relations. In the knowledge-based organizations the reciprocity should be highlighted more than ever as moral aspect is gaining more and more importance in employee relations in terms of transparency and equality. The empirical research conducted by Ling-hsing Chang and Lin (2015) reveals that organizational culture with an orientation to results and job-fit leads to better knowledge work performance that the culture oriented to strong control.

\section{Capability Match}

By identifying both-side (employee-employer) features combination which would differ due to organization sector and size the expectancy of organizational performance increases. Education system should provide the basic combination of capabilities which could be activated in a working environment. The job models and design which determine the quality of the work and resources accessible to perform the job (Bäck-Wiklund, van der Lippe, den Dulk, \& Doorne-Huiskes, 2011) are important factors in measuring capabilities fit.

\section{Engagement Match}

Engagement is seen as the main indicator for well performed work and just recently from the general workforce category, the investigation turned on knowledge workers (Li, Castaño, \& Y. Li, 2018, Jha, Pandey, \& Varkkey, 2018). Baron (2012) state that engagement taxonomy is binary - emotional and transactional. Engagement of knowledge workers is a strong premise as the motivation theory (also binary taxonomy - extrinsic and intrinsic) state that intrinsic motivation plays a significant impact on knowledge work performance. Employees' work engagement has been demonstrated to positively predict their work performance and innovation.

\section{Contribution Match}

According to Boxall (2013) contribution match is two folded. On one hand it shows the value added to the organization by the knowledge workers performance by using potential in the forms of know-how, applying problem solving skills and leadership abilities to solidify. On the other hand, the knowledge worker is verifying how does the company maintain the well-being and quality of life, as well as what is the possibilities of work-life balance. Researchers demonstrate relationship between person organization fit and innovative work behaviour (Afsar, 2016a, 2016b; Afsar \& Badir, 2017).

Based on the literature review we can conclude that organizational fit could be analysed by using three indicators and the following hypothesis is proposed:

H1: Organizational fit leads to better creative knowledge work performance.

\subsection{Mutuality versus reciprocity}

At the basic level, the Concise Oxford Dictionary (1996) offers that mutualism is: "The doctrine that mutual dependence is necessary to social well-being". This explanation indicates that this relation between parties is obligatory and creates subordination which could be expressed in the form of mutual gain. Another source of academic literature a concept of mutuality explains as "mutuality is an "institutionalised value-based model of reciprocity" which may be used to describe mutual models of ownership or decision-making, mutual methods of doing business of simply a mutual ethos" (Lea \& Mayo, 2002). This position is the one which explains the desired balance of power between workers and employee. The way the balance is being achieved depends on the general culture (Ali, Noordin, \& Achour, 2018) which forms attitudes, and current state of balance position (Olsen, 2016) which is expressed in the terms of the knowledge worker and work environment.

It is seen that the concept of power is closely related to mutuality and mutual gain. Huo, Tian, Tian, and Zhang (2019) give binary taxonomy of power - structural and behavioural. According to authors, social exchange theory has been widely used to understand structural power, which is understood as relational construct residing in the interdependence of exchange parties or described as a mutually rewarding process (Emerson, 1962). Resource dependence theory has been used to explain behavioural power within exchange relationships as organizations need to interact with other entities to obtain resources. This reciprocal exchange creates a reciprocal dependence between the exchange parties and a power relationship develops between them (Emerson, 1962). Their explanations indicate the necessity to investigate possible differences between mutuality and reciprocity which is presented in Table 2 . 
Table 2. Comparison of mutuality and reciprocity concepts (source: compiled by authors based on Hou et al., 2019; Dabos \& Rousseau, 2004; Marková, Graumann, \& Foppa, 1995; Emerson, 1962)

\begin{tabular}{|l|l|l|l|}
\hline \multicolumn{1}{|c|}{ Criteria } & \multicolumn{1}{|c|}{ Mutuality } & \multicolumn{1}{c|}{ Reciprocity } & \multicolumn{1}{c|}{ Author (year) } \\
\hline Theoretical Grounding & \multicolumn{1}{|c|}{ Social Exchange Theory } & \multicolumn{1}{c|}{ Resource Dependence Theory } & \multicolumn{1}{c|}{ Hou et al. (2019) } \\
\hline Degree & $\begin{array}{l}\text { To which the two parties agree on } \\
\text { their interpretations of promises } \\
\text { and commitments each party has } \\
\text { made and accepted }\end{array}$ & $\begin{array}{l}\text { To which agreement about the reciprocal ex- } \\
\text { change, given that commitments or contribu- } \\
\text { tions made by one party obligate the other to } \\
\text { provide an appropriate return }\end{array}$ & $\begin{array}{l}\text { Dabos \& Rousseau } \\
(2004)\end{array}$ \\
\hline Agreement & $\begin{array}{l}\text { Regarding one party's specific ob- } \\
\text { ligation }\end{array}$ & Regarding the reciprocal exchange & $\begin{array}{l}\text { Dabos \& Rousseau } \\
(2004)\end{array}$ \\
\hline Information & Assymetric & Symetric & $\begin{array}{l}\text { Marková et al. } \\
(1995)\end{array}$ \\
\hline Obligation & Technical & Moral & $\begin{array}{l}\text { Marková et al. } \\
(1995)\end{array}$ \\
\hline
\end{tabular}

To exemplify the argument the healthcare system could be taken as a paragon. Howieson (2016) could be quoted who makes perhaps a more powerful case by arguing that: "Mutuality $<\ldots>$ necessitates that all people with a significant interest in that provision seek awareness and accommodation of the interests of the public, and thereby seek to enable the people who make up those publics to enhance their well-being.". Based on this notion, it seems that public interest is if not the most essential then one of the predominant factors which determine influence and manifestation of mutuality. ICT with social media appear to be nexus which captures and involves society in the governance of organizations. Then it logically leads to the idea that mutuality has degrees of strength and the greater it is the more balanced performance could be expected. Beswick (2012) also considers two relevant and competing definitions: "a mutual relationship is one in which the relationship between service provider and user is transcended, through the users collectively delivering the service themselves, effectively doing away with the concept of service provider" and "mutualism could be described as a condition of interaction between two groupings where both derive decisive benefits; for example, increased sustainability".

There are some different opinion about mutuality as Suff and Williams (2004) based on their case study in manufacturing premise arrived at the conclusion that under conditions of liberal market and imbalance of power, mutuality is hardly achievable ambition in reality. The authors used four variables (employee voice, job security, quality of working life and job satisfaction, and trust) of employee perception to investigate partnership strategy and conceptualize the employment relations. But based on the realities of knowledge economy development and identifying other forms and dimensions of mutuality between creative knowledge workforce, the role of mutuality should be reconsidered.

\section{Learning}

Mutuality in organizations is realized by employee development programmes also known as the concept of Employee Led Development (ELD). By applying ELD the assumption that the benefits of learning apply equally to the organization and an individual employee is developed. Thursfield and Hamblett (2001) argue that learning is viewed as a social contract that binds organizations and individuals together in a common endeavour. It requires a sense of mutuality that is based on a voluntary agreement between parties and which gives benefits as mutual gains (Table 3 ).

Table 3. Mutual benefits of learning (source: Thursfield and Hamblett (2001))

\begin{tabular}{|c|c|}
\hline Organizational benefits & Knowledge workers benefits \\
\hline $\begin{array}{l}\text { Creates an organizational learning culture as individual become } \\
\text { more involved in knowledge acquisition }\end{array}$ & Opportunity to acquire a marketable qualification \\
\hline Increase in commitment to the organisation on the part of employees & Improvement of self-esteem \\
\hline $\begin{array}{l}\text { Increase the flexibility as employees become more willing and able } \\
\text { to take in extra responsibility and perform a wider variety of tasks }\end{array}$ & $\begin{array}{l}\text { Counteract and compensate for past negative learning } \\
\text { experiences }\end{array}$ \\
\hline Improves in the skill level on the workforce & Improve the quality of life generally \\
\hline Shifts from the conflict between management and workers & \\
\hline
\end{tabular}

Based on scientific interest and practical need for creation and development of workplace learning environments (e.g. Lancaster \& Di Milia, 2015; Hendriks, Sung, \& Poell, 2018) becomes a grounding to presuppose that learning is the strong factor to increase knowledge work performance at both levels - individual and organizational. 


\section{Well-being}

Well-being refers to health and quality of working life. In terms of mutuality of well-being forms healthy relations between employees and organization. Most definitions of healthy organization imply that these kind of organizations are those that meet both employee and workplace needs rather than pursuing one set of needs at the expense of others. Lewis with colleagues (2011) suggests that this approach addresses a dual agenda of employee quality of life and workplace effectiveness. Martela (2014) argues that well-being depends on processes within the work community which could be also understood as social support (George, 2015). Well-being is a largely important aspect for knowledge work performance (Palvalin, 2019) as it forms reciprocity and mutual trust.

\section{Trust}

Mutuality has a long history in social life as the form of organizing people for survival, so it would be not wise to omit it from the modern strategy of post-industrial management. In the dissertation of Matulevičienè (2018) the trust is defined as a construct which expresses the relationship between interacting and co-creating parties. This kind of relationship is indicated to be as the factor which facilitates organizational sustainability. There is also given the insight that trust is understood as interpersonal or interorganizaitonal construst, but there is the third kind of trust which appears between person and organization.

Mutual trust in scientific literature illustrates how the employee's trust organization and vice versa. Trust has an influence on knowledge sharing (Rutten, Blaas-Franken \& Martin, 2016) which also impact knowledge-centered culture (Peralta \& Saldanha, 2014). There are many other criteria to evaluate employee trust on organization: work safety, job quality, training (Matulevičienè, 2018).

Abovementioned analysis of mutuality incline to verify the following hypotheses:

H2: Mutuality leads to better creative knowledge of work performance.

H2a: Organizational fit mediates between mutuality and better creative knowledge work performance.

\subsection{Workplace empowerment}

The term of empowerment is related to the work of J. Rappaport (1984) who expressed the definition in the following manner: "Empowerment is viewed as a process: the mechanism by which people, organizations, and communities gain mastery over their lives". Although, George and Zakkariya (2018) indicate that Bandura's social cognitive theory (1977) with self-efficacy notion could be seen as the initial source of empowerment idea. Balancing powers and coming to the optimal operation is the aspiration of any system. Seminal work of Thomas and Velthouse (1990) explains power as having three different possible meanings: power as authority, power as capacity and power as energy.

In the scientific literature, there are three forms of empowerment are studied. Structural (also known as managerial or relational), psychological (individual) and community empowerment - all forms are captured in the empowerment theory (Zimmerman, 2000; Laschinger, Nosko, Wilk, \& Finegan, 2014; García-Juan, Escrig-Tena, \& Roca-Puig, 2018; Christens, 2019). All of them are important and influential in their own way but focusing on the investigation of organizational performance the structural empowerment captures the attention of the researchers the most.

Empirical evidence shows an interesting relationship between empowerment types. García-Juan, Escrig-Tena, and Roca-Puig $(2018,2019)$ has presented two studies of relations between structural, psychological empowerment and organizational performance. Their first research revealed that there is no confirmation on the direct link between structural and psychological empowerment (García-Juan et al., 2018) and the second study also based on empirical evidence shows that structural empowerment is positively associated with perceived organizational performance (García-Juan et al., 2019). What is more, the results uncover the role of psychological empowerment by stating that it does not mediate the abovementioned relationship, although it is a strong premise of organizational performance. Although, there are some studies that show, e.g. the moderating effect of team psychological empowerment on the relationship between abusive supervision and engagement (Kirrane, Kilroy, \& O'Connor, 2019). What is very specific to knowledge workers category, the empowerment is a technical action realized via digital solutions (Schneckenberg, 2009; Leyer, Richter, \& Steinhüser, 2019). Peluso, Innocenti and Pilati (2017) empirical study revealed that the work environment has a very strong motivating effect on knowledge workers as an element of total reward system.

Meanwhile, Singh and Sarkar (2018) followed Kanter's (1977) theory of structural empowerment where four aspects forms work environment, i.e.:

- Access to information refers to knowledge of organizational values, goals and policies, and refers to possession of knowledge and expertise required to work effectively.

- Access to support refers to the availability of feedback and guidance from supervisors, peers and subordinates (e.g., helpful advice from colleagues).

- Access to resources refers to access to funds, supplies, and physical time required to accomplish organizational goals.

- Access to opportunity refers to the availability of challenges, and rewards, and professional development opportunities within the workplace to increase knowledge and skills, development and recognition. 
It is assumed that work environments that provide access to these organizational conditions empower employees to accomplish their work in meaningful ways. Based on this theory the together with the Drucker's (1999) knowledge worker productivity theory and job design theory for knowledge workers (Moussa, Bright \&Varua, 2017), the following dimensions were created to explain the main points which should be highlighted in empowering knowledge workers.

\section{Autonomy}

Sustaining autonomy is the main feature of any system which indicates that already has enough power to work separately. An identity which is formed by skills, intelligence and experience point the moment when the employee could be called knowledge worker and be assigned to work role of different autonomy level (Tammelin, Koivunen, \& Saari, 2017). Gorji and Ranjbar (2013) conceptualized that psychological empowerment has an effect on employee creativity which is inseparable part of creative knowledge work performance. Creativity also tend to demand for strong work autonomy.

\section{Information Sharing}

Information sharing is one the most researched topic in knowledge management studies and at the same is the most important to knowledge worker's performance (Rutten, Blaas-Franken, \& Martin, 2016). Information sharing also important in creating and maintaining a supportive workplace environment as the norms, policies and organizational goals are the indicators of how innovative behaviour is understood and encouraged.

\section{Leadership}

Empowerment is also understood as people energizing capacity through leadership styles. As in the scientific literature, there are two main leadership styles - transactional and transformational - the latest one is showing and related to better innovative employee behaviour. Afsar, Yuosre F, Badir, and Hafeez (2016) argues that psychological empowerment differs from traditional empowerment which comprised a set of managerial practices solely focusing on delegation principles and that transformational leadership style is preferred over transactional as empirical evidence shows organizational performance. Leadership style has a strong impact on knowledge worker engagement (Li, Castaño, \& Li, 2018). By providing a strong role model, they activate a social learning process (Zohar, 2016) whereby employees observe their leaders to define value priorities and sense making in work environments and practices.

Based on the literature review we can conclude that workplace empowerment could be analysed by using three indicators and the following hypothesis is proposed:

H 3: Workplace empowerment leads to better creative knowledge work performance.

H 3a: Organizational fit mediates between workplace engagement and creative knowledge work performance.

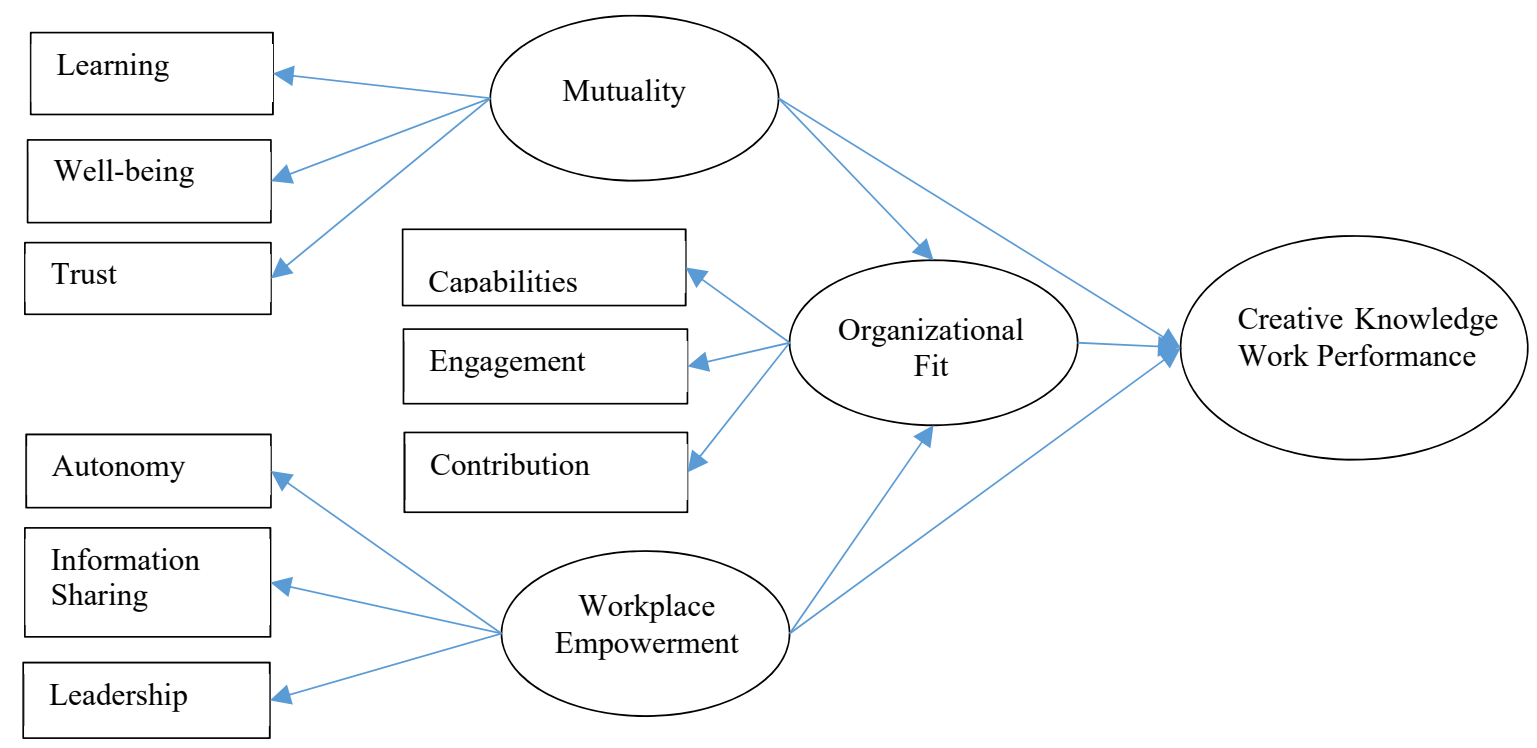

Figure 1. MEF model (source: authors) 


\section{Structural creative knowledge work performance model}

Figure 1 presents path analyses of three main elements that are assumed to have an influence on creative work performance. The following MEF (mutuality-empowerment-fit) model is the theoretically grounded model for further empirical research which would allow to validate the theoretical assumptions given here in the form of a hypothesis. The hypotheses are formed in the positivistic approach.

\section{Conclusions}

In knowledge-based organizations, knowledge work is seen as the main activity in value creation. According to Drucker, the individual level becomes the most relevant as well as the most challenging. The principles that were applied in the manufacturing environment are not the same as they should be applied in managing knowledge workforce. Knowledge workers do not obey traditional control mechanisms as well as their work performance is not so easily tracked by traditional productivity measurement. The latest proposal in the scientific discussion which would capture the social aspect of creative knowledge work performance was to investigate created value which is basically giving the organization competitive advantage.

After reviewing management literature in the fields of knowledge and human resource management as well as work economics and politics, the three elements were extracted which could predict creative knowledge work performance at the level of individual and organization. Empirical evidence is being collected by using questionnaire and the statistical analyses of collected data will append this theoretical research and constructed model.

\section{Disclosure statement}

Authors are declaring that they have no competing financial, professional, or personal interests from other parties in preparing this study and findings.

\section{References}

Abedi, E., Shamizanjani, M., Moghadam, F. S., \& Bazrafshan, S. (2018). Performance appraisal of knowledge workers in R\&D centers using gamification. Knowledge Management \& E-Learning, 10(2), 196-216. https://doi.org/10.34105/j.kmel.2018.10.013

Afsar, B. (2016a). The mediating role of psychological empowerment on the relationship between person organization fit and innovative work behaviour. Journal of Chinese Human Resources Management, 7(1), 5-26. https://doi.org/10.1108/JCHRM11-2015-0016

Afsar, B. (2016b). The impact of person-organization fit on innovative work behavior: The mediating effect of knowledge sharing behavior. International Journal of Health Care Quality Assurance, 29(2), 104-122. https://doi.org/10.1108/IJHCQA-012015-0017

Afsar, B., Yuosre F., Badir, B. B. S., \& Hafeez, S. (2016). Transformational and transactional leadership and employee's entrepreneurial behavior in knowledge-intensive industries. The International Journal of Human Resource Management, 28(2), 307-332. https://doi.org/10.1080/09585192.2016.1244893

Afsar, B., \& Badir, Y. (2017). Workplace spirituality, perceived organizational support and innovative work behavior: The mediating effects of person-organization fit. Journal of Workplace Learning, 29(2), 95-109. https://doi.org/10.1108/JWL-112015-0086

Ali, A. R. A. H., Noordin, K. B., \& Achour, M. (2018). The Islamic approach of obligations in mutual relations between employee and employer. International Journal of Ethics and Systems, 34(3), 338-351. https://doi.org/10.1108/IJOES-12-2017-0227

Bäck-Wiklund, M., van der Lippe, T., den Dulk, L., \& Doorne-Huiskes, A. (2011). Quality of life and work in Europe: Theory, practice and policy. Palgrave Macmillan. https://doi.org/10.1057/9780230299443

Baron, A. (2012). What do engagement measures really mean?. Strategic HR Review, 12(1), 21-25. https://doi.org/10.1108/14754391311282450

Beswick, E. (2012). A mutual NHS in Scotland: what are the leadership implications? Unpublished MSc coursework assignment. Stirling Management School, University of Stirling, Stirling.

Bosch-Sijtsema, P. M., Ruohomäki, V., \& Vartiainen, M. (2009). Knowledge work productivity in distributed teams. Journal of Knowledge Management, 13(6), 533-546. https://doi.org/10.1108/13673270910997178

Boselie, P. (2014). Strategic human resource management: A balanced approach (2 ${ }^{\text {nd }} \mathrm{ed}$.). Tata McGraw-Hill.

Boxall, P. (2013). Mutuality in the management of human resources: assessing the quality of alignment in employment relationships. Human Resource Management Journal, 23(1), 3-17, https://doi.org/10.1111/1748-8583.12015

Christens, B. D. (2019). Community power and empowerment. UK: Oxford University Press. https://doi.org/10.1093/oso/9780190605582.001.0001

Concise Oxford Dictionary. (1996). Oxford: Oxford University Press.

Čiutienė, R. (2006). Darbuotoju ir organizacijos interesu derinimas formuojant karjera: Daktaro disertacija. ISM Vadybos ir ekonomikos universitetas.

Dabos, G. E., \& Rousseau, D. M. (2004). Mutuality and reciprocity in the psychological contracts of employees and employers. Journal of Applied Psychology, 89(1), 52-72. https://doi.org/10.1037/0021-9010.89.1.52 
Dahooie, J. H., Arsalan, M. R. G., \& Shojai, A. Z. (2018). A valid and applicable measurement method for knowledge worker productivity. International Journal of Productivity and Performance Management, 67(9), 1764-1791. https://doi.org/10.1108/IJPPM-07-2017-0176

Drucker, P. (1999). Knowledge worker productivity: The biggest challenge. California Management Review, 41(2), 79-94. https://doi.org/10.2307/41165987

Emerson, R. M. (1962). Power-Dependance dependance Relationsrelations. American Sociological Review, 27(1), 31-41. https://doi.org/10.2307/2089716

García-Juan, B., Escrig-Tena, A. B., \& Roca-Puig, V. (2018). Empowerment in the public sector: Testing the influence of goal orientation. Public Personnel Management. https://doi.org/10.1177/0091026018819020

Garcia-Juan, B., Escrig-Tena, A. B., \& Roca-Puig, V. (2018). Psychological empowerment: antecedents from goal orientation and consequences in public sector employees. Review of Public Personnel Administration, 1-30. https://doi.org/10.1177/0734371X18814590

García-Juan, B., Escrig-Tena, A. B., \& Roca-Puig, V. (2019). The empowerment- organizational performance link in local governments. Personnel Review, 48(1), 118-140. https://doi.org/10.1108/PR-09-2017-0273

George, C. (2015). Retaining professional workers: what makes them stay?. Employee Relations, 37(1), $102-121$. https://doi.org/10.1108/ER-10-2013-0151

George, E., \& Zakkariya, K. A. (2018). Psychological empowerment and job satisfaction in the banking sector. Springer. 184.

Gorji, M. B., \& Ranjbar, M. (2013). Relationship between psychological empowerment of employees and organizational citizenship behavior. Australian Journal of Basic and Applied Sciences, 7(1), 67-75.

Griffin, B. (2015). Collective norms of engagement link to individual engagement. Journal of Managerial Psychology, 30(7), 847860. https://doi.org/10.1108/JMP-12-2012-0393

Haynes, B. (2008). An evaluation of the impact of the office environment onproductivity. Facilities, 26(5/6), 178-195. https://doi.org/10.1108/02632770810864970

Hendriks, S., Sung, S. Y., \& Poell, R. F. (2018). Learning paths of customer-facing professionals in the digital age. Journal of Workplace Learning, 30(5), 377-392. https://doi.org/10.1108/JWL-01-2018-0023

Howieson, B. (2016). The mutuality metaphor: understanding healthcare provision in NHS Scotland. Journal of Health Organization and Management, 30(4), 666-671. https://doi.org/10.1108/JHOM-07-2015-0100

Huo, B., Tian, M., Tian, Y., \& Zhang, Q. (2019). The dilemma of inter-organizational relationships: Dependence, use of power and their impacts on opportunism. International Journal of Operations \& Production Management, 39(1), 2-23. https://doi.org/10.1108/IJOPM-07-2017-0383

Iazzolino, G., \& Laise, D. (2016). Value creation and sustainability in knowledge-based strategies. Journal of Intellectual Capital, 17(3), 457-470. https://doi.org/10.1108/JIC-09-2015-0082

Iazzolino, G., \& Laise, D. (2018). Knowledge worker productivity: is it really impossible to measure it?. Measuring Business Excellence, 22(4), 346-361. https://doi.org/10.1108/MBE-06-2018-0035

Jha, J. K., Pandey, J., \& Varkkey, B. (2018). Examining the role of perceived investment in employees' development on workengagement of liquid knowledge workers: Moderating effects of psychological contract. Journal of Global Operations and Strategic Sourcing. https://doi.org/10.1108/JGOSS-08-2017-0026

Kähkönen, A.-K., \& Lintukangas, K. (2018). Key dimensions of value creation ability of supply management. International Journal of Operations \& Production Management, 38(4), 979-996. https://doi.org/10.1108/IJOPM-04-2016-0189

Kaplan, R., \& Norton, D. P. (2006). Alignment: Using the balanced scorecard to create corporate synergies. Harvard Business School Press.

Katou, A. A. (2017). How does human resource management influence organisational performance? An integrative approach-based analysis. International Journal of Productivity and Performance Management, 66(6), $797-821$. https://doi.org/10.1108/IJPPM-01-2016-0004

Kianto, A., Shujahat, M., Hussain, S., Nawaz, F., \& Ali, M. (2018). The impact of knowledge management on knowledge worker productivity. Baltic Journal of Management, 14(2), 178-197. https://doi.org/10.1108/BJM-12-2017-0404

Kirrane, M., Kilroy, S., \& O’Connor, C. (2019). The moderating effect of team psychological empowerment on the relationship between abusive supervision and engagement. Leadership \& Organization Development Journal, 40(1), 31-44. https://doi.org/10.1108/LODJ-07-2018-0252

Koopmans, L., Bernaards, C. M., Hildebrandt, V. H., Schaufeli, W. B., de Vet Henrica, C. W., \& van der Beek, A. J. (2011). Conceptual framework of individual work performance: a systemic review. Journal of Occupational Environment Medicine, 53(8), 856-866. https://doi.org/10.1097/JOM.0b013e318226a763

Kubik, G. H. (2015). Alpha societies and requisite variety: a projected framework for governance, education, and work in the $21 \mathrm{st}$ century. On the Horizon, 23(1), 16-24. https://doi.org/10.1108/OTH-05-2014-0018

Laihonen, H., Jääskeläinen, A., Lönnqvist, A., \& Ruostela, J. (2012). Measuring the productivity impacts of new ways of working. Journal of Facilities Management, 10(2), 102-113. https://doi.org/10.1108/14725961211218749

Lancaster, S., \& Di Milia, L. (2015). Developing a supportive learning environment in a newly formed organization. Journal of Workplace Learning, 27(6), 442-456. https://doi.org/10.1108/JWL-08-2014-0061

Laschinger, H. K. S., Nosko, A., Wilk, P., \& Finegan, J. (2014). Effects of unit empowerment and perceived support for professional nursing practice on unit effectiveness and individual nurse well-being: A time-lagged study. International Journal of Nursing Studies, 51(12), 1615-1623. https://doi.org/10.1016/j.ijnurstu.2014.04.010

Lea, R., \& Mayo, E. (2002). The mutual health service: how to decentralise the NHS. The Institute of Directors and the New Economics Foundation, London. 
Leyer, M., Richter, A., \& Steinhüser, M. (2019). Power to the workers: Empowering shop floor workers with worker-centric digital designs. International Journal of Operations \& Production Management, 39(1), 24-42. https://doi.org/10.1108/IJOPM-052017-0294

Lewis, S., Doorne-Huiskes, A., Redai, D., \& Barroso, M. (2011). Chapter 10, Healthy organizations. In M. Bäck-Wiklund, T. van der Lippe, L. den Dulk, \& A. Doorne-Huiskes (Eds.), Quality of life and work in Europe: Theory, practice and policy. Springer. https://doi.org/10.1057/9780230299443_10

Li, Y., Castaño, G., \& Li, Y. (2018). Linking leadership styles to work engagement: The role of psychological capital among Chinese knowledge workers. Chinese Management Studies, 12(2), 433-452. https://doi.org/10.1108/CMS-04-2017-0108

Ling-hsing Hsing Chang, C., \& Lin, T.-C. (2015). The role of organizational culture in the knowledge management process. Journal of Knowledge Management, 19(3), 433-455, https://doi.org/10.1108/JKM-08-2014-0353.

Loo, S. (2017). Creative working in the knowledge economy. Rouledge.

Marková, I., Graumann, C. F., \& Foppa, K. (1995). Mutualities in Dialogue. Cambridge University Press.

Martela, F. (2014). Sharing well-being in a work community - Exploring well-being-generating relational systems. In Neal M. Ashkanasy, Wilfred J. Zerbe, Charmine E. J. Hätel (Eds.), Emotions and the Organizational Fabric (Book Series: Research on Emotion in Organizations) (Vol. 10, pp. 79-110). Emerald Group Publishing Limited.

Matulevičienè, M. (2018). Organizacijos reputacijos ịtaka suinteresuotujų šaliu pasitikejjimui organizacija (daktaro disertacija). Kauno technologijos universitetas.

Moussa, M., Bright, M., \& Varua, M. E. (2017). Investigating knowledge workers' productivity using work design theory. International Journal of Productivity and Performance Management, 66(6), 822-834. https://doi.org/10.1108/IJPPM-082016-0161

Neely, A., Adams, Ch., \& Crowe, P. (2001). The performance prism in practice. Measuring Business Excellence, 5(2), 6-13, https://doi.org/10.1108/13683040110385142

Okkonen, J. (2004). The use of performance measurement in knowledge work context (Doctoral dissertation).

Olsen, K. M. (2016). The power of workers: Knowledge work and the power balance in Scandinavian countries. Employee Relations, 38(3), 390-405. https://doi.org/10.1108/ER-10-2014-0121

Palvalin, M. (2017). How to measure impacts of work environment changes on knowledge work productivity - validation and improvement of the SmartWoW tool. Measuring Business Excellence, 21(2), 175-190. https://doi.org/10.1108/MBE-05-20160025

Palvalin, M., Van der Voordt, Th. J. M., \& Jylhä, T. (2017). The impact of workplaces and self-management practices on the productivity of knowledge workers. Journal of Facilities Management, 15(4), 423-438. https://doi.org/10.1108/JFM-03-20170010

Pashkevich, N. (2016). Information Worker Productivity Enabled by IT System Usage: A Complementary-Based Approach (Doctoral dissertation).

Peluso, A. M., Innocenti, L., \& Pilati, M. (2017). Pay is not everything: Differential effects of monetary and non-monetary rewards on employees' attitudes and behaviours. Evidence-based HRM: a Global Forum for Empirical Scholarship, 5(3), 311-327, https://doi.org/10.1108/EBHRM-07-2015-0031

Peralta, C. F., \& Saldanha, M. F. (2014). Knowledge-centered culture and knowledge sharing: the moderator role of trust propensity. Journal of Knowledge Management, 18(3), 538-550. https://doi.org/10.1108/JKM-12-2013-0494

Ramirez, Y. W., \& Nembhard, D. A. (2004). Measuring knowledge worker productivity: a taxonomy. Journal of Intellectual Capital, 5(4), 602-628. https://doi.org/10.1108/14691930410567040

Rappaport, J. (1984). Studies in empowerment: Introduction to the issue. Prevention in Human Services, 3, 1-7. https://doi.org/10.1300/J293v03n02_02

Rutten, W., Blaas-Franken, J., \& Martin, H. (2016). The impact of (low) trust on knowledge sharing. Journal of Knowledge Management, 20(2), 199-214. https://doi.org/10.1108/JKM-10-2015-0391

Schneckenberg, D. (2009). Web 2.0 and the empowerment of the knowledge worker. Journal of Knowledge Management, 13(6), 509-520. https://doi.org/10.1108/13673270910997150

Shujahat, M., Hussain, S., Javed, S., Malik, M. I., Thurasamy, R., \& Ali, J. (2017). Strategic management model with lens of knowledge management and competitive intelligence: A review approach. VINE Journal of Information and Knowledge Management Systems, 47(1), 55-93. https://doi.org/10.1108/VJIKMS-06-2016-0035

Singh, M., \& Sarkar, A. (2018). Role of psychological empowerment in the relationship between structural empowerment and innovative behavior, Management Research Review, 42(4), 521-538. https://doi.org/10.1108/MRR-04-2018-0158

Suff, R., \& Williams, S. (2004). The myth of mutuality? Employee perceptions of partnership at Borg Warner. Employee Relations, 26 (1), 30-43. https://doi.org/10.1108/01425450410506887

Tammelin, M., Koivunen, T., \& Saari, T. (2017). Female knowledge workers and the illusion of working-time autonomy. International Journal of Sociology and Social Policy, 37(9/10), 591-604. https://doi.org/10.1108/IJSSP-08-2016-0100

Thomas, K. W., \& Velthouse, B. A. (1990). Cognitive elements of empowerment: An "Interpretive" model of intrinsic task motivation. The Academy of Management Review, 15(4), 666-681. https://doi.org/10.2307/258687

Thursfield, D., \& Hamblett, J. (2001). Mutuality, learning and change at work: the case of employee led development. Employee Relations, 23(4), 337-352. https://doi.org/10.1108/EUM0000000005686

Zimmerman, M. A. (2000). Empowerment theory: Psychological, organizational and community levels of analysis. In Handbook of Community Psychology (pp. 43-63). https://doi.org/10.1007/978-1-4615-4193-6_2

Zohar, D. (2016). The quantum leader: A revolution in business thinking and practice. Prometheus Books. 